\title{
Correction to: Benchmarking the software packages to model and assess the seismic response of unreinforced masonry existing buildings through nonlinear static analyses
}

\section{Serena Cattari ${ }^{1} \cdot$ Guido Magenes $^{2}$}

Published online: 21 April 2021

(c) Springer Nature B.V. 2021

\section{Correction to: Bulletin of Earthquake Engineering https://doi.org/10.1007/s10518-021-01078-0}

Due to proofing error author first \& last names were published in reverse order and has been now corrected as Cattari Serena and Magenes Guido.

Publisher's Note Springer Nature remains neutral with regard to jurisdictional claims in published maps and institutional affiliations.

The original article can be found online at https://doi.org/10.1007/s10518-021-01078-0.

Serena Cattari

serena.cattari@unige.it

Guido Magenes

guido.magenes@unipv.it

1 Department of Civil, Chemical and Environmental Engineering (DICCA), University of Genoa, Via Montallegro 1, 16145 Genoa, Italy

2 Department of Civil and Architectural Engineering (DICAR), University of Pavia, Via Adolfo Ferrata 3, 27100 Pavia, Italy 